\title{
Atypical Localised Benign Adnexal Tumor (Trichoblastoma) in a Dog
}

\author{
Ali Evren HAYDARDEDEOĞLU ${ }^{1 *}$,Irem ERGIN ${ }^{2}$,Hadi ALIHOSSEINI ${ }^{3}$,Ekrem Cagatay \\ COLAKOGLU $^{4}$, Ahmet BAYDIN $^{5}$
}

${ }^{1}$ Department of Internal Medicine, Faculty of Veterinary Medicine, Aksaray University, Aksaray/TURKEY
${ }^{2}$ Department of Surgery, Faculty of Veterinary Medicine, Ankara University, Ankara/TURKEY
${ }_{3,4,5}$ Department of Internal Medicine, Faculty of Veterinary Medicine, Ankara University, Ankara/TURKEY

\section{S U M M A R Y}

In this case; a 6-year-old, Setter breed female (neutered) localized benign adnexal tumor in a dog (Trikoblastoma) were detected. An irregular lesion on the upper right buttock limited solid construction, hard consistency, whitish gray mass complaints of $2.5 \times 1.8 \mathrm{~cm}$ with a lesion in the dog complaint was referred to the owner of the Ankara University Veterinary Faculty of Research Hospital. Routin blood work and urine analyses were in normal reference ranges in this case. Samples taken from the lesion for microbiological examination revealed no pathogens. At punch biopsy of the lesion, it was defined histopathologically as Trichoblastoma. The tumor was surgically excised. Any recurrence noted after surgery with no evidence of metastases on follow up chest radiographs. The authors performed the literature on the subject as far as he knew, and based on classical sources, this case in our country are considered as atypical localized Trichoblasto encountered the first time in a dog.

Key Words: Adnexal Tumor, Dog, Trichoblastoma

\section{Bir Köpekte Atipik Lokalize Benign Adneksiyal Tümör (Trikoblastoma)}

\section{ÖZET}

Bu olguda; altı yaşlı, Setter ırkı dişi (kısırlaştırılmış) bir köpekte lokalize benign adneksiyal tümör (Trikoblastoma) tanımlandı. Ankara Üniversitesi Veteriner Fakültesi Eğitim Araştırma Hastanesi'ne sahibi tarafından elden getirilen köpeğin klinik muayenesinde sağ üst gluteal bölgesinde, düzensiz yaklaşık $2.5 \times 1.8 \mathrm{~cm}$ çapında, solid yapıda, sert kıvamlı, beyazımsı gri renkli bir kitle saptand. Olgunun rutin kan tahlilleri ve idrar analizleri normal referans aralıklarında olduğu; mikrobiyolojik inceleme için ülseratif lezyonlu bölgeden alınan numunelerden herhangi bir patojen etken ya da etkenler saptanmadi. Lezyondan alınan punch biyopsi örneğinin histopatolojik incelemelerinde, olgu Trichoblastoma (benign adneksiyal tümör) olarak değerlendirildi. Tümör cerrahi olarak total eksize edildi. Herhangi bir nüks görülmedi ve takip edilen göğüs radyografileri sürecinde, cerrahi sonrası herhangi bir metastaz bulgusunun olmadığı görüldü. Konu ile ilgili yapılan literatür taramalarına ve klasik kaynaklara dayanarak, bu olgu, Ülkemizde, bir köpekte ilk defa rastlanan atipik lokalize Trichoblastoma olarak değerlendirildi.

Anahtar Kelimeler: Adneksiyal Tümör, Köpek, Trikoblastoma

*Corresponding author e-mail:ahaydardedeoglu@aksaray.edu.tr 


\section{INTRODUCTION}

Hair follicle tumors represent approximately $5 \%$ of all cutaneous neoplasms in dogs (1). Trichoblastomas previously termed as basal cell carcinoma (BCC) in dogs is a new name in veterinary field. They are classified as epithelial tumors including epidermal, follicular, sebaceous and sweat gland tumors (2). Trichoblastomas not commonly seen in dogs have solitary or multiple, dome-shaped, polypoid and alopecic nodules $(3,4)$. Most of the tumors are 1 to 2 $\mathrm{cm}$ in diameter but much larger and ulcerated lesions (exceeding $30 \mathrm{~cm}$ ) may occur. The head, neck and particularly the base of the ear are the typical locations of the lesions. Pigmented lesions may appear gray or blue on the skin. The average age of affected dogs are usually between 6 to 9 years old. Poodles and Cocker Spaniels have the increased frequency of BCC and trichoblastomas (5). However, Kerry Blue Terriers, Bichons Frises, Cockapoos, Shetland Sheepdogs and Siberian Huskies have the additional strong predispositions (6). The purpose of this case report is to point out the atypical localised benign adnexal tumor (Trichoblastoma) with an unusual predilection site in a dog.

\section{CASE REPORT}

A 6-year-old, neutered, female Setter breed dog having an irregular border-shaped, nonpruritic lesion over the right upper gluteal surface (approximately $2.5 \times 1.8 \mathrm{~cm}$ ) with no systemic symptoms referred to small animal veterinary teaching hospital (Figure 1). There was a truama history before the formation of the mass. The dog had been performing her duty as a narcotic detector for 3 years. Medical management of lesion by other veterinarians during 3 weeks had been failed. After physical examination; routin blood work, urine analyses and samples taken from the lesion for bacteriological and mycological examination were evaluated and punch biopsy was applied. In addition, thorax radiography was performed for the presence of metastases. Routin blood work and urine analyses were in normal reference ranges. Samples taken from the lesion for bacteriological and mycological examination revealed no pathogens.

Punch biopsy of the lesion showed histopathologically as trichoblastoma (Benign adnexal tumor). The tumor was surgically excised and fixed in 10\% formalin for histopathological examination. Paraffin sections (4 $\mu \mathrm{m}$ thickness) were prepared properly and stained with Haematoxylin-Eosin (HE). In microscopic sections, enlargement of superficial opening of the hair follicle in tissue covered with great amount of keratinized stratified squamous epithelium and growing benign tumor originated from external sheat of hair follicle were identified. Tumoral cells have basaloid shape in form of irregular masses (Figure 2). Any recurrence was noted after surgery with no evidence of metastases on follow up chest radiographs.

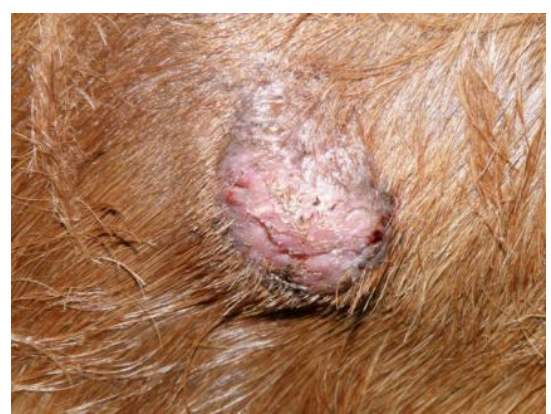

Figure 1. Over the right upper gluteal surface, close up picture of the lesion.

Resim 1. Sağ üst glutela bölgede lezyonun yakın resmi

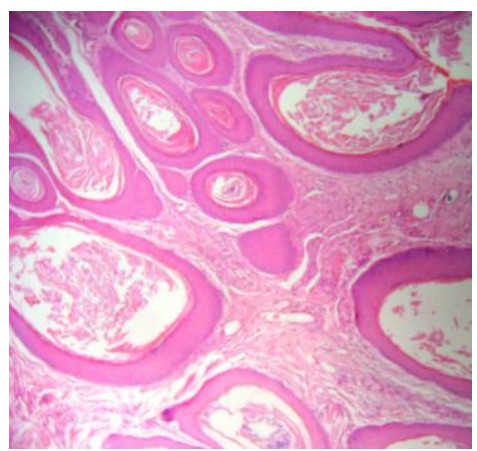

Figure 2. Microscopic appearance of Tumoral cells of benign mass have basaloid shape in form of irregular masses.HE $\times 400$.

Resim 2. Mikroskopik Görünüm Tümör hücrelerinin bazoloid şekle sahip düzensiz dağılımı HE $\times 400$. 


\section{DISCUSSION}

The differentiation of trichoblastomas from BCCs can be usually difficult. The development of trichoblastoma previously termed as BCC is the result of interaction between basal and mesenchymal cells. The basal cells (the germinative cells of the hair follicle) induce to specialized components of the follicle and trichoblastoma (7). While the histopathology of BCC includes anisokaryosis, nuclear hyperchromasia, mitotic activity, and mitotic atypia but these not seen in trichoblastomas. Trichoblastomas often comprise numerous winding epithelial cords and narrow trabeculae. This pattern has not been recognized in BCCs. In addition, trichoblastomas may contain the most of spindle cells but this phenomenon is rare in

\section{REFERENCES}

Meirelles AEWB, Oliverra EC, Rodrigues BA.Prevalência de neoplasmas cutâneos em cães da região metropolitana de Porto Alegre, RS: 1017 casos (2002-2007). Pesquisa Vet Brasil., 2010, 30, 968-973.

Goldschmidt MH, Schneider AC, Ferracone JD. Use of monoclonal antibodies as an adjunct to the diagnosis of epithelial skin tumors of the $\operatorname{dog}$ and cat using the EnVision Plus(R) system for the immunohistochemical detection of tissue antigens. In: K.L Thoday, C.S Foll, R. Bond (Eds.): Adv Vet Dermatol, Blackwell Science Oxford., 2002, 142-149.

\footnotetext{
Abramo F, Prates1 F, Cantıle C, Sozzı S, Polı A. Survey of canine and feline follicular tumours and tumour-like lesions in central Italy. J Small Anim Pract., 1999, 40, 479481.
}

BCCs. The stroma of trichoblastomas has minimal cellularity and often contains follicular papillary mesenchymal bodies which are not found in BCCs (8).

Predilection sites of trichoblastoma in dogs are the head, neck and the base of the ear (5). In the present case, the tumor situated in caudal part of body was remarkable. The presence of trauma and wound in formation of adnexal tumor has not been reported in veterinary literatures. In the case presented here, the forming of trichoblastoma following the wound after trauma and not responsive to medical therapy are also noticable.

Although no predisposing factor could be identified in the case, the association between narcotic substances and skin tumors need to more research in future.

Campos AG, Cogliat1 B, Guerra JM, Matera JM. Multiple Trichoblastomas in a dog. Vet Dermatol., 2014, 25(1), 48-e19.

Bevier DF, Goldschmidt MH. Epithelial tumors and tumor-like lesions. Compend Contin Educ., 1981, 3, 389-98.

Goldschmidt MH, Shofer FS: Skin tumors of the dog and cat, Pergamon Press, Oxford, 1992.

Goldschmidt MH., Dunstan RW., Stannard AA: Histological classification of epithelial and melanocytic tumors of the skin of domestic animals. In: M.H. Goldschmidt (Ed.): World Health Organization International Classification of Tumors in Domestic Animals, Armed Forces Institute of Pathology, 1998, 11-101.

Brooke JD, Fitzpatrick JE, Gloıtz LE. Papillary mesenchymal bodies: a histological finding useful in differentiating trichoepitheliomas from basal cell carcinomas. J Am Acad Dermatol., 1989, 21, 523-528. 